Relations industrielles

Industrial Relations

\title{
Psychologie industrielle
}

\section{Arthur Tremblay}

Volume 2, numéro 5, janvier 1947

URI : https://id.erudit.org/iderudit/1023834ar

DOI : https://doi.org/10.7202/1023834ar

Aller au sommaire du numéro

Éditeur(s)

Département des relations industrielles de l'Université Laval

ISSN

0034-379X (imprimé)

1703-8138 (numérique)

Découvrir la revue

Citer cet article

Tremblay, A. (1947). Psychologie industrielle. Relations industrielles / Industrial Relations, 2(5), 4-8. https://doi.org/10.7202/1023834ar

Tous droits réservés (C Département des relations industrielles de l’Université Laval, 1947
Ce document est protégé par la loi sur le droit d'auteur. L'utilisation des services d'Érudit (y compris la reproduction) est assujettie à sa politique d'utilisation que vous pouvez consulter en ligne.

https://apropos.erudit.org/fr/usagers/politique-dutilisation/ 
semble que la Commission ou le Procureur général prenne l'initiative des procédures judiciaires au lieu de laisser cette responsabilité à l'initiative privée.

3. Les deux organisations demandent la refonte complète de la Loi des différends ouvriers de Québec devenue désuète.

4. La C.T.C.C. présente une demande qui s'inspire de C.P. 1003 et même du nouveau projet de la Loi d'Enquête sur les Relations et les Différends industriels en requérant qu'il soit prévu que les différends concernant l'interprétation ou la violation d'une convention collective soient réglés par une décision finale et obligatoire-et que dans le cas de congédiement d'un employé pour activités syndicales, la Commission de relations ouvrières ait le pouvoir d'émettre une ordonnance obligeant l'employeur à réinstaller l'employé ainsi congédié.

5. La C.T.C.C. demande également l'établissement d'une cour supérieure d'arbitrage équivalant à un tribunal d'appel. Les parties pourraient en appeler de toute décision arbitrale ayant force exécutoire.

6. Les organisations demandent enfin de nouvelles pénalités pour certaines infractions basées sur chaque jour d'offense. Elles demandent aussi l'aggravation des pénalités actuelles.

Nous sommes certains que le Bulletin des Relations industrielles a fait oeuvre utile en reproduisant les revendications des principales organisations ouvrières de la province au sujet de notre Code du Travail. Nous n'avons pas reproduit celles du Congrès canadien du Travail pour l'excellente raison que nous ne les avons pas pour le moment. La presse nous a informés cependant que le Congrès canadien du Travail (C.I.O.) s'est déclaré favorable à la centralisation en matière de Code du Travail. Il veut que les provinces n'agissent, en somme, que comme de simples services administratifs sous la juridiction de l'autorité fédérale, celle-ci instituant une cour d'appel ayant pouvoir de casser les décisions des organismes provinciaux chargés de l'application du Code.

Nous sommes à un point crucial dans le développement de la législation ouvrière et dans la lutte pour l'autonomie provinciale. Chacun doit se faire un devoir d'apporter sa collaboration pour que la province de Ouébec ait une législation aussi parfaite que possible assurant ainsi la paix sociale dans la justice et l'équité.

\section{La Direction}

\section{NOS COLLABORATEURS:}

\footnotetext{
Jean-Pierre Després, D.S.Soc., membre du personvel du Bureau international du travail à Genève, professeur à la Faculté des Sciences sociales de l'Université Laval.

Arthur Tremblay, L.S.Soc., M.Ed,, assistant-directeur de l'Ecele de Pédagogie de l'Université Laval.
}

\section{PSYCHOLOGIE INDUSTRIELLE}

\author{
(Suite de la page 8)
}

Voilà pourquoi, s'inspirant des données de la psychologie sociale, elle étudiera la dynamique des relations personnelles à l'intérieur d'une entreprise, les rapports psychologiques qui unissent le patron et ses ouvriers et ceux-ci entre eux. Ce faisant, dans certains cas, elle découvrira la véritable cause de problèmes auxquels on aura jusque là cherché une explication trop superficielle. Elle montrera, par exemple, que souvent certains conflits ouvriers ont un autre notif plus profond que l'insuffisance des salaires, qu'ils originent plutòt dans !'attitude psychologique du patron envers ses ouvriers ou inversement.

Elle s'attachera ensuite à analyser les exigences objectives particulières de l'entreprise, les qualifications, les aptitudes, que requièrent les diverses fonctions, les multiples tâches qu'il faut y remplir. Elle classifiera celles-ci en termes des aptitudes physiques ou psychiques qu'elles demandent. Elle construira les instruments psychologiques nécessaires à l'appréciation de ces aptitudes chez les individus. Elle organisera par conséquent, un système d'examens (tests, entrevus, etc.) qui permettront, lors de l'embauchage, d'éliminer les candidats inaptes, et, par la suite, à «distribuer», le personnel aux endroits où il donnera son rendenent maximum. Mais de nouveau, il faut mentionner cet aspect de la psychologie industrielle dont nous parlions tantôt, les relations personnelles entre ouvriers et contremaitres et patrons. Dans cette distribution de chacun à la tâche qui lui convient, elle tiendra compte des personnalités individuelles, et non pas seulement de ces caractéristiques généralement appel-es aptitudes. Elle veillera, par exemple, à ce qu'il y ait non seulement équation entre les exigences d une tâche donnée et les aptitudes du travailleur, mais aussi accord et harmonie potentiels, sinon actuels, entre les personnalités de ceux qui sont appelés à vivre coude à coude pour ainsi dire et à collaborer quotidiennement de façon très étroite.

Ce sont là croyons-nous, les tâches essentielles de la psỳchologie industrielle. On en reconnait généralement l'importance; mais ce qu'on semble voir moins aisément, c'est que le premier venu n'est pas en mesure de les bien remplir. En bien des cas, une interprétation par trop simpliste des nobiles humains, une confiance trop facile en son expérience des hommes, et surtout, la primauté factice de l'aspect économique rejettent ces questions à l'arrière plan des préoccupations de ceux qui ont la responsabilité de diriger les entreprises. Hanté par l'expression matérielle de leur fonctionnement, par le chiffre d'affaires et les considérant pour ainsi dire, en eux-mêmes, absolument, comme des réalités existant par soi, on oublie les facteurs humains ou ne leur accorde qu'une attention distraite et superficielle. Lè problème n'est pourtant pas si simple. Pour n'étre pas toujours immédiates, les sanctions que provoque une attitude semblable se produisent inéluctablement, même sur le plan économique. Beaucoup de grèves sont incompréhensibles si l'on ne fait intervenir l'explication psychologique d'un « moi collectif » trop longtemps opprimé qui veut s'affirmer, en tarit que «moi », beaucoup plus qu'il ne désire un accroissement de bien-être matériel. 


\section{Face à l'avenir}

\section{LA PARTIICIPATION OUVRIÈRE}

Les deux revendications essentielles de la classe ouvrière après la première Grande Guerre ont été la journée de huit heures et le respect de la liberté syndicale. De nos jours ces revendications semblent avoir été satisfaites dans la plupart des pays, grâce à l'action persévérante des syndicats ouvriers et à l'intervention gouvernementale, bien que certains secteurs de la classe patronale aient mis quinze années à se convaincre qué la liberté syndicale découle de la démocratie politique et de l'économie capitaliste.

Depuis six ou sept ans des progrès considérables ont été accomplis dans le domaine des relations industrielles. Le syndicalisme s'est discipliné et, d'autre part, la classe patronale a accepté le syndicalisme comme un fait social permanent. L'Etat cherche constamment à rapprocher le Capital et le Travail en les associant étroitement à sa législation, soit sur le plan de la consuitation, soit dans le champ d'application des lois. De la récente expérience de l'économie de guerre et de l'évolution des idées au cours de cette période se dégagent maintenant des tendances significatives au sujet des relations industrielles. Bien que certaines de ces tendances ne soient pas encore précises, elles révèlent cependant que des problèmes sont posés et qu'il importe de les étudier pour les résoudre dans le sens de l'intérêt général. Parmi ces problèmes, il en est un qui ressort nettement de l'ensemble des revendications ouvrières d'après-guerre, aussi bien en Amérique qu'en Europe: c'est celui de la participation ouvrière à la gestion des entreprises. Je n'exposerai ici que les grandes lignes de cette question, sans porter de jugement pratique sur les difficultés que comporte l'application du principe de la participation ouvrière à la gestion.

Tel qu'entendu ici, la participation à la gestion de l'entreprise, c'est la participation non seulement à l'oeuvre de production, mais aussi à l'administration de l'entreprise. Elle implique donc des aspects techniques et économiques qui exigent dans les rangs des syndicats la présence de travailleurs doués de connaissances administratives relativement étendues. Il $\mathrm{y}$ a lieu de distinguer, ainsi que je l'ại déjà fait (voir Bulletin no 3 , premièremière série: les Comités d'entreprises en France), la participation sous forme de conseil. la participation sous forme de contrôle et la participation sous forme de cogestion.

C'est cette dernière qui constitue une innovation, car elle permet aux travailleurs d'une entreprise d'influencer le développement de celle-ci au même titre que les représentants des actionnaires. Le bureau de direction comprend alors deux catégories de directions: lcs uns représentent les intérêts du canital et les seconds les droits des travailleurs. La particination sous forme de conseil est déià en pratique au Canàda nar les comités mixtes à la production. Les comités d'entreprises en France et dans quelques autres pavs de l'Europe sont une application de la participation sous forme de contrôle. On prévoit que ces comités ne sont qu'une étape vers la véritable congestion. Déià les syndicats francais donnent à leurs militants une formation administrative et commerciale en raison de cette évolution vers la cogestion.

Ce développement de la particioation ouvrière à ia gestion de l'entreprise. quelle que soit sa forme. est un indice aui ne trompe pas. Le travailleur doit être intégré à l'entreprise. mais non par le truchement de vagues comités de coopération qui cachent bien mal le désir de brider l'élan syndicaliste. Je ne discute pas pour le moment le principe de la véritable cogestion. Cette réforme de structure, serait-elle désirable et acceptée par l'ensemble du patronat, 'que la classe ouvrière, pas encore suffisamment préparée à ce rôle; enregistrerait un échec, car elle ne semble pas encore préte, du moins au Canada, à assumer ce rôle. C'est parce que je suis un partisan sincère du syndicalisme et que je crois à la contribution essentielle qu'il apportera éventuellement à la transformation de notre régime économique et social, que je fais cette restriction qui n'a d'ailleurs qu'un caractère transitoire.

Mais si la cogestion n'est peut-être pas réalisable actuellement, il en va autrement des deux premières formes de participation à la gestion. Certaines compagnies américaines, sous l'influence d'Eric Johnson, exprésident de la Chanbre de Commerce des Etats-Unis, ont organisé des « junior boards», composés de représentants des travailleurs, qui assistent les bureaux de direction. Il ne saurait être question d'instituer pareille réforme dans l'idée d'endiguer la vague syndicaliste. Toute réforme de structure devra se faire avec la collaboration des syndicats ouvriers, sinon ce sera la faillite. D'autre part, il n'est pas question non plus de confier des responsabilités mal définies à des personnes qui n'ont pas les capacités requises.

En effet, le principe de la hiérarchie des fonctions ne doit jamais être mis de côté. L'application d'un système quelconque de participation à la gestion, quelle que soit sa forme, implique une hiérarchie, c'est-à-dire un ordre. Je ne vois pas comment des représentants des travailleurs dans un organisme de gestion seraient recrutés en majorité dans le département des manoeuvres. De même, comment concevoir que les représentants désignés par les travailleurs ne soient pas des éléments de première qualité. En d'autres termes, la participation à la gestion exige un aménagement rationnel de la représentation des travailleurs dans les conseils de gestion, problème que les conventions collectives de travail devraient prévoir et résoudre.

Du côté de la classe ouvrière, la participation à la gestion implique une prise de conscience nouvelle, c'està-dire l'acquisition de notions tećhniques et économiques indispensables à quiconque aspire à des responsabilités dans l'administration d'une entreprise. On ne doit pas se préoccuper uniquement de former des chefs syndicaux, mais également de donner une éducation technique et économique à tous les travailleurs qui montrent des dispositions suffisantes: C'est sur le plan de l'industrie dans son ensemble qu'il faut envisager la formation d'éléments ouvriers et syndicaux aptes à la gestion. L'expérience que poursuit depuis deux ans la commission d'apprentissage de l'industrie de la chaussure prouve qu'il est possible d'élever le niveau des connaissances professionnelles des travailleurs.

Je viens simplement d'esquisser quelques-uns de: aspects de la participation ouvrière à la gestion de l'entreprise. Ce schéma n'avait qu'un but: provoquer l'étude d'un problème qui deyra être résolu un jour plus ou moins prochain, à savoir l'intégration du travailleur dans la structure économique. De même que pour la liberté svindicale, les eniployeurs qui seront les premiers à aborder cette question sans l'escamoter seront en mesure de s'adapter rapidement aux exigences du progrès social. 


\section{THE LABOR CODE}

(Continued from page 1)

Provincial Government by certain labour organizations with a view to having the aforesaid acts amended. Therefore, we quote hereinbelow:

1 -extracts from the memorandum submitted by the Quebec Provincial Federation of Labour on behalf of the Trades and Labour Congress of Canada (American Federation of Labour);

2 - extracts from the memorandum of the Canadian and Catholic Confederation of Labour.

\section{Memorandum of the Quebec Provincial Federation of Labour}

\section{Labour Relations Act}

This Act has been somewhat amended at the last session of the Legislature, but as with all human undertakings it is far from being perfect, there is therefore nothing surprising that in the course of its application some weaknesses as well as advantages have developed. For instance Section 4 says: "every employer shall be bound to recognize as the collective representative of his employees the representatives of an association comprising an absolute majority of his said employees and to negotiate with them, in good faith, a collective labour agreement. . ." Section 42 defines the penalties to which an employer is liable if he fails to recognize the representatives of his employees.

In spite of this, quite a number of employers have refused to abide by this Act. It starts at the taking of the secret ballot ordained by the Board; instead of facilitating said ballot, as prescribed by Section 8 , all possible and imaginable obstacles are put in the way, quite often an inappropriate location is designated to hold the election, pressure is brought about on the employees, everything goes, when finally, and in spite of all, the certification is granted; then, the employer refuses to meet the other party (Section 11), he ignores the repeated invitations of the conciliator, he invokes a lot of excuses, makes pressure upon pressure, theatens to close his factory, so much so that the employees are getting discouraged, relinquish the certification and finally another company union is born. These are the facts.

We claim that every infraction should be prosecuted without delay, that the penalties provided for by Section 42 should be increased, the fine should be applied for each day or part of a day during which the employer or association of employers refuse to negotiate with the representatives of employees duly recognized by the Commission.

Section 49 stipulates that "No penal prosecution may be taken without the written authorization of the Board or the consent of the Attorney General". We believe it would be better if either the Board or the Attorney General assume charge of the prosecution instead of letting an individual or an association do it, as this Section seems to imply.

We urge also that the Board should motivate all its decisions and notify the interested parties accordingly.

Those whom we are representing did not ask for this legislation, but once on the Statute Books we have accepted it and given it our full support. If employars are not compelled to live up to it in the prescribed delay, it would be just as well to erase it from the Statutes; we will then learn to rely uniquely upon our union contracts and obtain our rightful revendications through our economic strength, without being hindered by Section 24 which declares a strike illegal unless its provisions have been fully complied with.

There are altogether too many delays in the application of the Act, delays prejudicial to the workers in many instances. The same could verily be said in regard to the Act concerning boards of conciliation and arbitration (Chapter 167. R. S. Q.. 1941). This Act should be entirely modified, it is far from covering everything it should; for instance, it says that no claim or dispute shall be referred to councils of conciliation or arbitration in any case in which there are less than ten employees interested in such claim or dispute. We could even say that it is coming in direct conflict with the Labor Relations Act; furthermore, Sections 10 to 18 seem to be useless now, they are dealing with councils of conciliation while actually a single conciliator, appointed by the Minister of Labor, does whatever such councils were supposed to do.

There is also the remuneration of members of such conciliation councils; the fee stipulated by Section $\mathbf{3 0}$ is altogether too low; we would like to see members of such boards well remunerated for their services although we do object to the numerous delays and to the little time devoted to its meetings; a session lasts an hour or two, and it is then adjourned for a week, sometimes more, too much time lost altogether.

While we are on the subject, we urge the necessity of increasing the fee of witnesses appearing before arbitration or conciliation boards; they are allowed a miserable fee of $\$ 2.00$ per day; we submit that they should be entitled to at least $\$ 6.00$ a day or $\$ 4.00$ a half day.

\section{Labour Disputes in Public Services}

\section{Status of Crqwn Companies' Employees}

A certain legislation known as the Public Services Employees Disputes Act has been adopted in 1944; its aim is well defined by Section 5 which states: "strikes or lock-outs are prohibited in all circumstances"; it abrogated the Act respecting the arbitration of disputes between certain charitable institutions and their employees. (Chapter 194, R. S. Q., 1941).

We are of the opinion that Section 2 covers too much ground and that time has arrived to revise this particular section. Prohibiting a strike, at all times, seems to be rather drastic as it deprives the working class of the only means of defense it possesses when all other means of conciliation or arbitration have failed.

A tendency seems to be developing to deprive all employees of public utilities from the benefits of social legislation as soon as those companies are nationalized. The fact that a private company becomes an emanation of the Crown is not a reason to deprive its employees from being included, protected or subject to or by any existent labor legislation.

We bcg the Minister of Labor to submit this case to the legal advisers of his Department to see if there is any possibility that the employees of Public Utilities Companies be rightfully entitled to the full benefits of all labour legislation.

\section{Memorandum of the Canadian and Catholic Confederation of Labour}

\section{Iabour Relations Act and}

\section{Public Services Employees Disputes Act}

By way of amendments to the aforesaid acts, the C.C.C.L. suggests:

1. That subsections 1,2 and 3 of Section 2 , in both acts, be repealed and replaced by a single subsection specifying that only persons engaged at confidential work or empowered to hire or dismiss employees shall be excluded from the definition of the word "employee";

2. That the Labour Relations Board be authorized to publish the documents it has in its possession; that it be compelled to state its reasons for accepting or refusing to issue a certificate of recognition, and moreover, that its decisions be published in the Quebec Ufficial Gazette or some other official report;

3. That the Labour Relations Act formally compel employers to receive, under penalty of severe punitive sanctions, at the first regular meeting, the authorized negotiators of a union recognized by the Board;

4. That the law clearly specify that the Labour Relations Board has full powers to institute proceedings against those who violate any provision of the Labour Relations Act or Public Services Employees Disputes Act; 
5. That it be provided that all disputes concerning the interpretation or violation of a collective agreement be settled by a decision which would be final and binding, and that, in the case of the dismissal of an employee for union activities, the Labour Relations Board be empowered to issue an ordinance compelling the employer to reinstall the employee so dismissed;

6. That the negotiation and arbitration proceedings provided tor the passing of collective agreements be explicitly made applicable to the renewal of collective agreements with or without amendments;

7. That an employer who has signed a collective agreement and has the work carried out by sub-contractors should be held responsible for such sub-contractors observance of the wages and working conditions stipulated in the collective agreement as in the case of a decree enacted under the Collective Agreement Act;

8. That the right to arbitration be recognized for all employees, including provincial government employees, and that the provisions of 10 George VI, Chapter 21, which deprive male and female teachers of such right or which limit the said teachers' right to arbitration, be repealed;

9. That the agreements negotiated be posted up and be kept posted up in a suitable place, except when printed and distributed to the interested parties;

10. That the law explicitly provide that a certificate may be granted to a federation of unions and that a suitable procedure be established to verify the representative character of such federation.

\section{The Quebec Trade Disputes Act}

As the C.C.C.L. suggested in the report it submitted last year, this Act should be entitled "An Act respecting Conciliation and Arbitration" and should undergo several amendments in view of the considerable evolution of labour legislation of these last few years.

The C.C.C.L. insists more particularly upon the following modifications:

1. That all employers subject to the Labour Relations Act and the Public Services Employees Disputes Act be also subject to the Quebec Trade Disputes Act, and that the words "employer", "employee" and "dispute" have respectively the same meanings in the three aforesaid acts;

2. That a conciliation service, as effective as possible, be established under the authority of a director of industrial relations;

3. That a limited delay (ten days) be fixed for the appointment of its respective arbitrator by each party whenever an arbitration board is being formed, and that should one or both of the parties fail to comply with such provision, the Minister of Labour would make the necessary appointments;

4. That a limited length of time be given to arbitration boards to hear a dispute and report on same to the Minister of Labour, and that the procedure followed before an arbitration board be as expeditive and simple as possible;

5. That, as regards the choice of the place at which arbitration boards shall hold their meetings, the Province be considered as divided into districts after the actual division of the Province into judicial districts, and that the said boards be compelled to sit in the district in which the dispute has occurred, either at the chief-place of such district or within the very municipality of the dispute, unless the parties have otherwise agreed in a clause of the collective agreement or in some other manner;

6. That, as to matters pertaining to wages, the Act lay down as a rule that the award of an arbitration board be retroactive from the date on which the formation of such arbitration board was requested. Exceptions to this rule would be left to the discretion of the arbitrators;

7. That the Act provide remuneration not only for the arbitrators, but also for a representative of each party before an arbitration board;

8. That there be established a superior court of arbitration to which the parties may appeal against any enforceable award. The awards of this court should be published in the Quebec Official Gazette, or, at least, in the bulletins issued by the Information Service of the Provincial Department of Labour.
The foregoing memoranda are presently beimg studied by the provincial authorities and we do not intend giving, in this article, our opinion of the amendments suggested but merely wish to point out the most important of the proposed modifications:

1. It is to be noted that the Quebec Provincial Federation of Labour (American Federation of Labour) did not ask for the adoption of a National Labour Code; indeed, the very fact that it suggests the amendment of the Labour Relations Act, the Public Services Employees Disputes Act and of the Quebec Trade Disputes Act means that it does not wish them to be repealed but improved. Nevertheless, the Trades and Labour Congress continues its campaign in favour of centralization. On the other hand, the C.C.C.L.'s attitude is well known to all; it is absolutely in favour of the maintenance of provincial autonomy in matters of industrial relations.

2. The labour associations complain that employers resort to dilatory measures in order to avoid the obligation of negotiating collectively with the organization which has been certified by the Board. Together they request that the Board or the Attorney General take it upon themselves to institute court proceedings instead of leaving such a responsability to private initiative.

3. The two organizations demand the complete revision of the Quebec Trade Disputes Act which is now quite obsolete.

4. In a request which it has drawn from P.C. 1003 and the draft Bill entitled the Industrial Relations and Disputes Investigation Act the C.C.C.L. demands that it be provided that disputes concerning the interpretation or violation of a collective agreement be settled by a final and binding decision, and that the Labour Relations Board be given the power to issue an ordinance compelling an employer to reinstall the employee whom he has dismissed for union activities.

5. The C.C.C.L. also requests the establishment of a superior court of arbitration similar to a court of appeal. The parties at strife could appeal to such a court against any enforceable arbitration award.

6.-Finally, the organizations demand that certain offences entail new penalties based on each day's infraction. They also demand the augmentation of the penalties actually provided for.

We believe that the Bulletin des Relations industrielles is performing useful work in informing its readers of the demands of the most important labour organizations of the Province as concerns our Labour Code. We have not given here the demands of the Canadian Labour Congress as we do not have them at hand. However, the press has informed us that the Canadian Labour Congress (C.I.O.) declared itself in favour of the centralization of canadian labour legislation. It would like to have the provinces act as mere administrative services under the jurisdiction of the Federal Government which would institute a court of appeal empowered to annul the decisions of the provincial bodies entrusted with the enforcement of the Code.

A crucial point has been reached in the development of labour legislation as well as in the struggle for provincial autonomy. Every one must do his share towards giving the Province of Québec legislation that will ensure social peace through justice and equity.

The EDITORS 


\section{PSYCHOLOGIE INDUSTRIELLE}

$\mathrm{La}$ psychologie industrielle, comme la psychologie professionnelle d'ailleurs «doit sa naissance au remarquable ouvrage de Münsterberg, intitulé Psychologie und Wirtschaftateben (Leipzig, 1912). Cet éminent psychologue fut chargé de rechercher les causes psychologiques qui pourraient avoir une influence sur les accidents occasionnés par les tramways. En étudiant les aptitudes des conducteurs et les qualités requises pour cet office, ii aboutit à cette conclusion que le quart au moins des sujets examinés ne réunissaient point les conditions voulues pour cette charge; et, en outre, il se trouva - résultat fort important - que, dans cet examen, la classification des sujets faite dans le laboratoire coincida presque exactement avec celle que les chefs de services avaient établie eux-mêmes d'après leurs observations quotidiennes faites sur leur personnel. On constatait avec évidence, la nécessité et la possibilité de sélectionner le personnel, afin d'obtenir le meilleur rendement possible et d'éviter les pertes et les accidents 》.

Les résultats pratiques obtenus par ces essais et par beaucoup d'autres qui furent tentés par la suite, contribuèrent à faire connaître et à accréditer ce genre d'investigation. Et, aujourd'hui, sinon encore dans notre province, du moins dans beaucoup de pays, européens et surtout aux Etats-Unis, les applications industrielles de la psychologie ne se comptent plus, et un grand nombre d'entreprises recourent avec profit aux services de psychologues spécialisés dans l'étude du problème général de l'adaptation de l'homme à son travail professionnel.

\& Les applications industrielles de la psychologie portent principalement sur quatre genre de relations: a) entre le travailleur et son travail; b) entre le travailleur et son contremaitre; c) entre le travailleur et la direction de l'entreprise; d) entre le travailleur et ses compagnons de travail. ${ }^{2}$

Sans doute n'est-ce point dans le choix de ces cadres généraux de travail que la psychologie industrielle se distingue des autres disciplines, comme la direction du personnel, par exemple, et qu'elle participe de façon originale et particulière à la solution des problèmes humains d'une entreprise. Mais, tout en étant ordonnée au bien commun dé l'entreprise à l'instar des autres services, la psychologie industrielle y remplit des fonctions qui lui sont propres.

En termes généraux, nous dirions que son principal rôle est d'abord, d'observer, de décrire et d'expliquer le jeu des forces psychologiques qui sont mises en branle iorsqu'un groupe d'individus, patrons et ouvriers, gérants et employés, se trouvent soumis, dans les cadres d'une entreprise, aux exigences de ia production industrielle ou du commerce. Son rôle est également de définir les conditions psychologiques qui assureront une efficacité maxima à l'activité collective des participants de l'entreprise.

Nous reconnaissons que cette conception de la psychologie industrielle ne reflète peut-être pas l'opinion qu'on en a généralement, même parmi les spécialistes de cette science. Pour un grand nombre, en effet, elle se limite exclusivement, ou à peu près, à l'étude des problèmes de la sélection et du rendenent des travailleurs. Il est vrai que pendant de nombreuses années, la psychologie industrielle n'a pas eu d'autres préoccupations, qu'elle a fait ses preuves et montré son abilité dans ce domaine d'abord. Mais, nous semble-t-il, si elle ne veut pas demeurer dans une erreur que nous appellerions l'obsession du rendement matériel immédiat, en termes d'unités de production, la psychologie industrielle doit étendre ses cadres, élargir ses horizons. Elle doit voir, dans lentreprise industrielle ou commerciale, le problème d'un groupe d'hommes soumis ensemble, aux exigences d'une action commune d'un genre particulier.

(1) Barbado, M. "Introduction à la psychologie expérimentale", page 450. Paris, Lethielleux, 1931.

(2) Viteless, Morris S., "Industrial Psychology", pp. 54-55, N.Y. Norton \& Co., 1932.

(Suite da la page 4)

\section{CONGRÈS DES RELATIONS INDUSTRIELLES}

Il nous fait plaisir d'annoncer à nos lecteurs que le succès remporté l'an dernier par le Congrès des Rolations Industrielles a encouragé la Faculté des sciences sociales de l'Université Laval, à en organiser un second en 1947.

Ce 'Congrès qui sera tenu à Québec, en avril prochain, durera deux jours et aura comme thème général la convention collective de travail.

Durant la première journée, les délégués étudieront la préparation et la technique préliminaire à la convention collective; le règlement des griefs issus de l'application de la convention; les vices généraux des conventions collectives.

Le problème si épineux de la sécurité syndicale fera l'objet des études de la seconde journée; il sera envisagé sous ses aspects moral et légal ainsi que du point de vue des employeurs et des syndicats ouvriers.

Les congressistes auront l'occasion de participer aux forums qui suivront chacun des exposés.

Le programme définitif sera publié dans le prochain numéro du Bulletin en même temps que la liste des conférenciers.

\section{INDUSTRIAL RELATIONS CONFERENCE}

We are pleased to inform our readers that the success achieved last year by the First Industrial Relations Conference has led the Faculty of Social Sciences of Laval University to organize another Congress, in 1947

It will be held at Québec, in April and will last two days. The subject-matter will be the Collective Labour Agreement.

During the first day, the auditors will study the preparation and preliminary technique to the collective agreement; the settlement of grievances arising out of the application of the agreement; the general defects of the agreements.

The ever present problem of Union Security will be studied during the second day. It will be considered from its moral and legal aspects and also from the employers' and trade-unions' points of view.

The congressmen will have the opportunity to participate in the discussions which will follow every lecture.

The definite programme will be published in the next issue of the Bulletin at the same time as the list of the lecturers. 